\title{
Auto-economics: the Tata Nano
}

Jeevan William D Almeida, Sandeep Jony, Nikhil Chandran, Keerthi Purushotham \& Ashish Gupta

The Nano has made news worldwide since its unveiling in January of 2008. This car is a milestone in the history of automobile manufacturing. As economists, we have found the Nano extremely interesting as it is expected to have far reaching effects not only in the automobile industry, but also spark the aspirations of millions of people for owning a car that were deprived of this pleasure prior to the launch of Nano.

\section{Background}

Cars are considered a luxury in developing countries, especially in a country like India where the ownership rate is just 7 cars for every 1000 people. This is unsurprising since India's average family annual income is around INR120000 (US\$3000), while the cheapest car available in the market is the Maruti Suzuki 800 at a price of INR 00000. This shows that owning a car is not a very affordable option for most households. Besides, in India, two wheelers are available between the price range of INR25000 to INR45000. These vehicles are preferred by the middle class, who account for about $20 \%$ (300 million) of the population (Ramprasad 2007). Consequently, there are nearly 58 million two wheeler owners in India (Doval 2009). However, travelling by two wheelers is a risky option considering India has one of the highest road accident related deaths in the world.

Ratan Tata, the CEO of Tata Motors, launched the Nano not as an example of overdone opulence but because he wanted to provide the typical family of four currently travelling on a bike a much safer transportation option and at a comparatively cheaper price. None of the car manufacturers had ever thought of converting these people into car owners before. Tata Motors decided to provide a cheaper car for this section of the market expecting 
households that own motor bikes would graduate to cars. Henry Ford had a similar vision in 1908 to mass produce cheap cars and did so by introducing the Model T .Tata Motor's efforts to develop a cheap car resulted in the launch of the Nano in January 2008 at a price of just INR100000 (US\$2500). This relatively low price was achieved by a number of innovations at the design, manufacturing and supply chain levels.

\section{Economies of Scale and Scope}

The Nano features some interesting innovations such as an entirely new rear mounted $623 \mathrm{cc}$ engine was developed. The use of light-weight composite materials, single wipers instead of two, car wheels at the extreme ends and three lug nuts instead of four on the car wheels have helped reduce the car cost. In addition Tata concentrated on the Nano's fuel economy and internal space efficiencies.

Similarly, it is the economies of scale and scope that are at the heart of the dynamics of the Nano's potential to become a success. For example, at the manufacturing level, common tooling processes were introduced. This reduced the cost of operations and increased the life of the dyes threefold. Besides, Tata Motors worked in conjunction with their suppliers like Krug to reduce paint shop costs (Tata Motors, nd).

They also plan to produce this car in the future by sending knocked down kits to franchisee based assembly plants where the car assembly would take place. This would reduce labour related costs for Tata Motors. At the supply chain level, Tata Motors have entered into long term agreement with suppliers. This has helped them obtain a maximum number of components from a minimum number of suppliers. These innovations have helped in reducing the price of the car, thereby drastically reducing the cost of an entry level car (Scanlon 2009).

\section{The Impact of Price Discrimination}

Henry Ford of Ford Motors was also successful in introducing the Model $\mathrm{T}$ at a cheap price mainly due to his innovation in mass producing cars on assembly lines .This had 
significantly reduced the costs of the Model T. Similarly, a number of subsidies for the Nano were given by the state government of Gujarat to attract Tata Motors to set up the manufacturing plant in Sanand district of Gujarat as they were optimistic about the demand and success of Nano. These subsidies amounting to INR 60000 per car helped Tata motors to reduce the final cost of the car (Asia news network 2008). As a result, the cost of an entry level car in India has been reduced by $30 \%$ making cars suddenly more affordable. This would finally result in an affordable car to the 58 million two wheeler owners and could help in increasing the market size for cars by about $65 \%$ in India, where most of the car owners in this market would be first time car buyers (CRISIL 2008).

Nano has been attractively priced between the previous existing cheapest car and two wheelers. Introducing this car at different price levels has helped Tata Motors follow third degree price discrimination in this market. Their models range from the Nano BS II at the price of INR115361 to the Nano LX BS III at the price of INR172361 (Tata Motors 2010). This practice enables Tata to capture more of the market surplus for itself as well as increasing the affordability to a larger set of consumers.

The Third Law of Demand is also applicable to an assessment of the Tata Nano. Consider that if two varieties of the Nano are transported and an identical additional fixed cost is applied to the price of both models, buyers would now find the more expensive version cheaper in terms of its relative price to the lower cost version. There is prima facie evidence of this effect when you consider that $80 \%$ of the bookings that have taken place thus far are for the top end models and just $20 \%$ of the bookings were for the lower end models (Business Standard 2009). Most of the lower end models have been booked by people who had never owned a car or who have only ever owned two wheelers perhaps making their relative price decisions being based on the basic Nano and a two-wheeler rather than two versions of the Nano. This fact also shows that the Nano is being purchased by first time car buyers. Besides a survey conducted in the small cities of the state of Punjab in India found that majority of the people owning bikes would move to the Nano (Batt 2008). 
Price discrimination may well also be happening in terms of the geographic location of the consumers. Consider that the Nano has been envisioned as affordable and alluring for the lower middle class living in tier- 2 with a population between 1 and 4 million \& tier 3 cities with a population of less than 1 million as most of the bookings have not taken place in the major metropolitan cities. In tier 2 and tier 3 cities the average income is comparatively less than in metropolitan cities. Furthermore people in these cities consider buying cars as a matter of prestige and a source of one's achievement in life. The Nano's attractive price could easily satisfy this aspiration of the people.

\section{Cross Price elasticity}

The price of the Nano deliberately makes it a close substitute to some products in the two wheeler market. Besides, the Nano in a few years from now could adversely impact the second hand car market and reduce the price of second hand cars by around 20 to 30 percent and their sale by 35 percent (Reuters 2008). This could make second hand cars a lot cheaper bringing them even closer to the price of two-wheelers.

In smaller Indian cities, public transport is not very well developed and is also unreliable. As a result people there tend to rely on private transport. For example, school-going children in tier 2 cities travel by the three-wheeled auto rickshaw for transportation to schools. The Nano could provide a safer and better public transport alternative due to its affordability and revolutionise personal transportation. Conversely it could also contribute to congestion in the urban cities due to the sluggish development of urban transportation.

There exists a strong relation between fuel prices and the demand for automobiles as they are complementary to each other. Whenever petrol prices go up people tend to prefer fuelefficient cars over fuel-inefficient ones. The population of consumers from whom the majority of the Nano's demand is expected is arguably extremely price sensitive. Hence, it is possible that there may be less demand for the Nano in those circumstances. While the mileage of the Nano is rather good at $26 \mathrm{~km} / \mathrm{l}$, it is far bettered by the average two wheeler 
mileage of 50 to $60 \mathrm{~km} / \mathrm{l}$. If the price of petrol were to go up, then mileage figures could render the car a less attractive proposition.

\section{Impediments for Nano}

The current aggregate production of the Nano is just 30000 units a year against the current demand estimated by the 203000 bookings. As demand outstrips supply, economic theory mandates that the prices of the good would have to increase to clear the market or there would be a loss of surplus due to a condition of shortage at the announced price. This means the Tata has to strive hard to increase the production and to avoid losing consumers to other prospective manufacturers. Due to short supply, a black market is developing as some current owners and people waiting for their cars to be delivered are selling their cars at a premium of $10-30 \%$ (News Centre 2009). As a result, the Nano has become expensive for the consumers thereby decreasing consumer surplus.

The practice of Equated Monthly Instalments (EMI), a type of loan repayment, for the Nano further reduces the consumer surplus. Tata Nano bookings had to be made by paying $70 \%$ of the car's price. A majority of the Nano buyers have therefore had to book the Nano by taking automobile loans .This means that they have to begin making repayments right from the start of the loan. However, many of the car buyers have received delivery dates amounting to waiting periods of at least a year. If a buyer orders a Nano, he would have to pay INR 70000 as the booking amount for the base model. Suppose he borrows a loan at 11\% interest per annum, for a 3 year period. He would then have to pay an EMI of INR2291.71 for 36 months starting from the day of taking the loan. This would result in the buyer paying around $16 \%$ more for the car than the actual car price while not being able to utilise the car for at least a year. This further decreases their surplus, and makes the car yet more expensive for them. As a result a number of buyers have actually cancelled their orders. These cancellations amount to around 10 to $15 \%$ of the orders (Rebello and Rishi, 2009). So, in the short run, the car seems to be more expensive than its actual cost for both consumers as well as for Tata. 


\section{Externalities}

The most severe impacts of this car could be with respect to pollution in India. The carbon emissions in India for a motorbike are $29 \mathrm{~g} / \mathrm{km}$ while for the Nano it is $101 \mathrm{~g} / \mathrm{km}$. If a family of four currently travelling by a motorbike would graduate to the Nano, the emissions per family would be higher. Besides if, just like Ford's Model T, conservatively, around 16 million Nano's were to be sold in 20 years, the amount of carbon emissions would be 3 times more than if the same people were to use bikes instead.

On the other hand, due to the Nano's innovations, global car manufacturers are now increasingly using Indian automobile engineering talent to develop their small cars. This can be seen by the increased R\&D spends in India by Suzuki and Nissan (Reuters 2010 \& NASSCOM 2009). Further, the subsidies offered by the different states to the car manufacturers will assist in increasing such manufacturing activities in India, which will have a positive impact on the development of this industry and the Indian economy in general.

At present the Nano seems to be unable to deliver on Tata's initial promise of providing a "one lakh car" (INR100000) due to the low production volumes of the car and the blackmarket and long queues this has resulted in. However, in the long run, as the new Nano plant becomes operational, Tata Motors would be able to meet the demand for this phenomenon of a car. However, the prices for a Nano would also depend on a lot of associated factors such as the cost of raw materials which Tata Motors would have to manage effectively to keep the car affordable to the masses. Otherwise the Nano would end up being just another car in the Indian car market. 


\section{References}

- Asia News Network (2008) "60000 rupees subsidy for each 100000 rupee car", retrieved on 10 May 2008, < http://www.asianewsnet.net/news.php?sec=1\&id=2602>

- Batt, S (2008) "RIMT Prof conducts survey on Tata Nano", retrieved on 10 May 2008, $<$ http://www.expressindia.com/latest-news/rimt-prof-conducts-survey-on-tatanano/268453/>

- Business Standard ( 2009) "High-end versions drive early Nano bookings", retrieved on 14 may 2010,

< http://www.business-standard.com/india/news/high-end-versions-drive-early-nanobookings/354636/>

- CRISIL (2008) “Tata Nano Impact Analysis”, retrieved 05 April 2010, $<$ http://www.domainb.com/finance/rating/crisil/images/CRISIL_Research_impact_analysi s_tata_nano.pdf >

- Doval, P (2009) “China, India to be fastest-growing car markets”, The Times of India, retrieved on 11 May 2010,

<http://timesofindia.indiatimes.com/business/india-business/China-India-to-be-fastestgrowing-car-markets-JD-Power/articleshow/4386767.cms>

- NASSCOM (2009) “Renault-Nissan to scale up India research facility”, retrieved 10 May2010, < http://www.nasscom.in/Nasscom/templates/NormalPage.aspx?id=55494>

- News Centre (2009) “Tata Nano a hit in second hand car market too”, retrieved 10 May2010, <http://www.moneycontrol.com/news/cnbc-tv18-comments/tata-nanohitsecond-handcar-market-too_416234.html >

- Ramprasad, C (2007) “India's middle class failure”, Prospect Magazine, retrieved on 12 May 2010, < http://www.prospectmagazine.co.uk/2007/09/indiasmiddleclassfailure/ >

- Rebello, J and Rishi, N (2009) “EMI spurs Nano cancellations", DNA Read the world, retrieved 10 May 2010, <http://www.dnaindia.com/money/report_emi-spurs-nano-cancellations_1281312>

- Reuters (2008) “Tata Nano to dampen demand for bikes, second hand car", retrieved on 12 May 2010, <http://in.reuters.com/article/idINIndia-31358420080111> 
- Reuters (2010) “Japan's Suzuki to invest \$553.8 mln in engines, India R\&D”, retrieved on 12 May 2010, <http://in.reuters.com/article/idINIndia-47142920100323>

- Scanlon, J (2009) “What can Tata Nano teach Detroit?”, Businessweek Online, retrieved on 09 May 2010,

< http://search.ebscohost.com/login.aspx?direct=true\&db=a9h\&AN=37032447\&site=ehostlives

- Tata Motors (2010) Price List, retrieved 04 April 2010, $<$ http://tatanano.inservices.tatamotors.com/tatamotors/index.php?option=com_booking\& task=pricelist\&Itemid $=303>$

- Tata Motors (nd) Nano Diaries, retrieved on 28 June 2010, $<$ http://tatanano.inservices.tatamotors.com/tatamotors/index.php?option=com_content\&t ask=view\&id=184\&Itemid=210\&limit=1\&limitstart=1> 